\title{
BMJ Open Quality Governing patient safety in field hospitals: lessons for the future
}

\author{
Samantha Machen
}

To cite: Machen S. Governing patient safety in field hospitals: lessons for the future. BMJ Open Quality 2021;10:e001541. doi:10.1136/ bmjoq-2021-001541

Received 26 April 2021 Accepted 19 July 2021

\section{Check for updates}

(C) Author(s) (or their employer(s)) 2021. Re-use permitted under CC BY-NC. No commercial re-use. See rights and permissions. Published by BMJ.

Department of Applied Health Research, UCL, London, UK

Correspondence to Dr Samantha Machen; samantha.machen.16@ucl. ac.uk

\section{INTRODUCTION}

Across the world, the COVID-19 pandemic has brought an unprecedented risk to the delivery and availability of healthcare. As hospital admissions soared with patients hospitalised with the effects of the virus, there was a growing demand to increase bed capacity. To increase this supply, field hospitals were commissioned. In the UK, nine field hospitals were commissioned, with their objectives to reduce deaths and free capacity in acute providers and allow referring hospitals to maintain flow in and out of their surge capacity. ${ }^{1}$ When the National Health Service (NHS) Nightingale Hospital London opened, it had a capacity of 500 beds, increasing to 4000-5000 if needed. Likewise, the NHS Nightingale Hospital Birmingham had a capacity of 596 and increasing to 4500 . These field hospitals were set up rapidly, in a matter of months, with a focus on performance and operationalisation. However, a key question to consider and reflect on is how patient safety has been governed in this new delivery of care. Reflecting on this can ensure that safety and quality remains at the forefront of any future field hospitals.

\section{GOVERNING SAFETY AT PACE: A MOVE TO PROACTIVE SAFETY MONITORING}

Formal governance arrangements for patient safety include performance indicators that can be applied at national (macro), organisational (meso) and local service (micro) levels. ${ }^{2}$ Organisations (meso) and local (micro) services will commence measurement of certain indicators-for example dose omission rates-in response to national (macro) polices and guidance. Organisations' and local areas' understanding of safety can be argued to be reactivethat is, reacting to when things go wrong and addressing a specific incident reported. ${ }^{34}$ Also known as a Safety I approach; this approach is regularly seen in safety governance across the NHS. As committees focus on incidents reporting, there is less room for the proactive management of safety-referred to as a Safety
II approach. ${ }^{5}$ Safety I and Safety II approaches to the governance of safety differ in that the latter seeks to learn from excellence, as well as incidents, and views safety as not the avoidance of errors, but the reliance on Human Factors principles to make systems safer and more resilient. Safety in local areas, for example, wards, can be seen as a function of their past errors and socialisation of risks to staff members. For example, a unit's approach to medication safety may be heavily affected by a serious incident that has happened previously. However, when field hospitals are set up with no historical context of local safety issues, how does this challenge our understanding of 'traditional' safety governance?

The NHS Nightingale Hospital London was set up with the Bedside Learning Coordinator (BLC) model incorporated into dayto-day patient care. ${ }^{6}$ This model is based on collecting safety and performance insights by BLCs (improvement specialists working nonclinically) at the point of the delivery of care to patients by speaking to clinical staff and patients about safety or performance concerns. These insights were logged onto the ImproveWell app ${ }^{7}$ and actioned by members of the improvement team. For Nightingale London 2-opened in January 2021 as a bedded unit focusing on the care of patients with long-term rehab needsthis model was well embedded into daily practice. The Nightingale 2 had a new workforce, new formal governance arrangements and a new cohort of patients and therefore, the BLC model provided important safety surveillance data.

The role of systems thinking, or a 'human factors', approach to the assurance of patient safety is well established as an aim for organisations $^{8}$ and highlights the need to learn from excellence, when things go well, and not focus only on errors. With the establishment of the Nightingale field hospitals, there was no historical safety data-for example incidents-and therefore proactive management of safety risks was essential. In this setup, with unknown risks, a proactive view of 
safety referred to a need to look at safety risks that do not necessarily seem apparent due to the absence of errors and incident reports. This specific context meant that there was a need to focus on proactive safety monitoring as well as the 'softer' aspects of safety which were gained from the insights collected from the BLC. For example, these insights referred to issues relating to the design of the wards, handover routine and communication about safety issues. Staff insights on safety were collected daily and, therefore, safety risks were identified and attended to at an early point as opposed to at the point of an incident occurring.

It is an important shift in mentality to view safety in a proactive way, and without historical data or local safety culture, field hospitals have the opportunity to start afresh and look at safety through a systems lens. The setup of the Nightingale field hospitals has furthered our understanding for the need for systems thinking and Safety II approaches to safety governance as key improvements were made to safety through this model. For example, insights gained from front-line staff identified that handover of safety issues were thwarted by a lengthy central handover in the morning which took time away from individual handovers between nurses from day and night shifts. This was seen as a potential risk, where key safety information may not be handed over in time, for example, recent blood glucose readings or risk assessments being due. BLCs worked with the staff on the ward to shorten the central handover to three 'key safety points' for all staff before moving to longer one-on-one handovers with individual nurses.

\section{LESSONS FOR THE FUTURE}

For field hospitals in the armed forces, there is a focus on making the system (here being the deployed staff) as safe as possible. To do this, there is a focus on competencies for all staff being completed before deployment-for example, the defence operational nursing competencies (DONC) $)^{9}$ - and mission-specific training (eg, simulation) prior to deployment. Field hospitals that have been set up at pace, similar to the Nightingale hospitals, may have a high turnover of staff, with differing skills and experience, and therefore ensuring competencies in a similar way to the DONC would help ensure safer systems. Second, the role of the BLC has emerged as an example of how proactive safety governance, or a Safety II approach, can be implemented. By collecting information about safety issues before they become incidents, we can work towards a safer system overall. This is a model that can be implemented across healthcare providers alongside traditional safety assurance methods-for example incident reporting-and help enable organisations move towards a Safety II way of thinking.

Twitter Samantha Machen @samantha_machen

Funding The authors have not declared a specific grant for this research from any funding agency in the public, commercial or not-for-profit sectors.

Competing interests None declared.

Patient and public involvement Patients and/or the public were not involved in the design, or conduct, or reporting, or dissemination plans of this research.

Patient consent for publication Not required.

Provenance and peer review Not commissioned; externally peer reviewed.

Open access This is an open access article distributed in accordance with the Creative Commons Attribution Non Commercial (CC BY-NC 4.0) license, which permits others to distribute, remix, adapt, build upon this work non-commercially, and license their derivative works on different terms, provided the original work is properly cited, appropriate credit is given, any changes made indicated, and the use is non-commercial. See: http://creativecommons.org/licenses/by-nc/4.0/.

\section{REFERENCES}

1 de Val J, Sohal G, Sarwar A, et al. Investigating the challenges and opportunities for medicines management in an NHS field Hospital during the COVID-19 pandemic. Eur J Hosp Pharm 2021;28:10-15.

2 Ramsay AIG, Turner S, Cavell G, et al. Governing patient safety: lessons learned from a mixed methods evaluation of implementing a ward-level medication safety scorecard in two English NHS hospitals. BMJ Qual Saf 2014;23:136-46.

3 Hollnagel E. Proactive approaches to safety management. The Health Foundation, 2012.

4 Fyhr A, Ternov S, Ek Å. From a reactive to a proactive safety approach. Analysis of medication errors in chemotherapy using General failure types. Eur J Cancer Care 2017;26:e12348.

5 Hollnagel E, Wears RL, Braithwaite J. From Safety-I to Safety-II: A White Paper 2015.

6 Shand J, Allwood D, Lee N, et al. Systematically capturing and acting on insights from front-line staff: the 'Bedside Learning Coordinator'. BMJ Qual Saf 2021;30:509-12.

7 ImproveWell. Available: https://www.improvewell.com/

8 NHS Improvement. The NHS Patient Safety Strategy - Safer culture, safer systems, safer patients; 2019.

9 Royal College of Nursing. A professional resource for nurses new to defence; 2018. 